\title{
Ocupações urbanas como repertório confrontacional dos movimentos de luta por moradia
}

\author{
Urban squatting as a confrontational \\ repertoire of the housing movements
}

Thêmis Amorim Aragão [I] Ana Carolina Maria Soraggi [II]

Filipe Souza Corrêa [III]

\begin{abstract}
Resumo
Dada a importância que os movimentos sociais tiveram na construção de uma agenda política para Habitação de Interesse Social no Brasil, este artigo tem como objetivo discutir as possibilidades de repertório confrontacional dos movimentos de moradia num contexto sociopolítico caracterizado por uma inflexão ultraliberal e com significativas transformações na relação entre Sociedade Civil e Estado. Para isso, partimos de um estudo de caso de ocupação urbana, no qual relatamos o processo de ocupação e consolidação da vila Eliana Silva (Belo Horizonte/MG). A análise desse histórico permitiu destacar estratégias e repertórios de ação que explicitam a luta pelo cumprimento da função social da propriedade, bem como uma necessária reflexão sobre possibilidades de variação desse repertório de confronto na nova conjuntura.
\end{abstract}

Palavras-chave: movimentos sociais urbanos; ocupações urbanas; habitação de interesse social; política habitacional; confronto político.

\begin{abstract}
Given the importance of social movements in building a political agenda for Social Housing in Brazil, this article aims to discuss possibilities for a confrontational repertoire of the housing movements in a sociopolitical context characterized by an ultraliberal inflection, with significant transformations in the relationship between Civil Society and State. To accomplish this, we present a case study of an urban squatting in which we analyze the process of settlement and consolidation of Vila Eliana Silva (Belo Horizonte, State of Minas Gerais). The analysis highlights the strategies and repertoires of action that reveal the struggle to fulfil the social function of property, as well as a necessary reflection on possibilities of variations in this confrontational repertoire in the new conjuncture.
\end{abstract}

Keywords: urban social movements; urban squatting; social housing; housing policy; political confrontation. 


\section{Introdução}

A ocupação de áreas urbanas que não cumprem sua função social tem sido um elemento recorrente do repertório de ação dos movimentos de moradia. A importância dessa estratégia tem sido reforçada pela recente inflexão ultraliberal no Brasil - cujo ápice se dá com a eleição de Jair Bolsonaro (PSL - atualmente sem partido) para a Presidência da República - e que coloca as ocupações urbanas como alvo de ações repressivas. Assim, como ato de resistência, a tática de ocupação organizada de vazios urbanos constitui elemento fundamental da estratégia de luta pelo direito à moradia por parte de alguns movimentos de moradia no Brasil.

Os processos políticos que se desenvolveram no Brasil desde as Jornadas de Junho de 2013, somados aos reflexos das transformações sociais que aconteceram ao longo da década de 2000, conduziram ao afloramento do conflito político entre os defensores de um Estado de Bem-Estar e os defensores da liberalização das políticas sociais. Em relação à questão da demanda por moradia digna, a mudança na configuração político-partidária no poder desde o golpe de 2016 - que resultou no impeachment da presidenta Dilma Rousseff (PT) - significou um profundo revés na política habitacional construída nas últimas duas décadas. ${ }^{1}$

Desde o início do século XX, quando o Estado passou a intervir, as políticas habitacionais brasileiras foram construídas como uma tentativa de dar respostas às demandas latentes por moradia. A análise histórica dessas políticas aponta as conquistas e os reveses da constante pressão política feita pela sociedade civil organizada em torno de uma agenda de Reforma Urbana. Numa análise das políticas urbanas e habitacionais mais recentes, ressalta-se a configuração de um arcabouço institucional importante no início dos anos 2000, a partir da aprovação da lei federal n. 10.257, de 10 de julho de 2001, e da criação do Ministério das Cidades, em 2003.

A lei federal n. 10.257/2001 (Brasil, 2001), chamada Estatuto da Cidade, regulamenta os artigos 182 e 183 da Constituição Federal de 1988 (Brasil, 1988), que tratam da Política Urbana. Considerando o perfil dos governos ao longo da década de 2000, é importante observar que as bases sobre as quais foram construídas as políticas urbanas e habitacionais são resultados dos esforços dos movimentos de luta pela Reforma Urbana, desde antes do período da ditadura militar. A inflexão ultraliberal que se deu na política brasileira em meados da década de 2010 se coloca como um grande obstáculo para a atuação dos movimentos sociais em prol da questão da moradia e do direito à cidade, especialmente pelo seu caráter contestador de uma ordem jurídico-política que favorece o direito à propriedade em detrimento do cumprimento da sua função social.

Este artigo está dividido em três seções. Na primeira seção, o resgate da construção do arcabouço legal e institucional da política urbana nacional existente foi feito dando especial enfoque aos processos que conduziram à edificação de uma agenda política para a habitação de interesse social no País, bem como à importância da atuação dos movimentos sociais de moradia como atores relevantes para a construção dessa agenda. Na segunda seção, são apresentadas algumas questões relativas às possibilidades da ocupação urbana como 
repertório confrontacional dos movimentos de luta por moradia, em um contexto em que a eleição do presidente Bolsonaro traz transformações significativas nos termos da relação entre sociedade civil organizada e Estado, opondo-se radicalmente aos elementos simbólicos e discursivos, bem como dos repertórios de ação coletiva que caracterizaram a construção de uma agenda progressista de políticas urbanas em nível nacional. A terceira seção apresenta o relato da experiência de mobilização em torno da ocupação e consolidação da vila Eliana Silva, localizada na Região Metropolitana de Belo Horizonte, destacando que, mesmo em um contexto político, no geral, mais favorável ao diálogo com os movimentos sociais, a resultante política nem sempre correspondeu aos anseios e urgências da realidade das cidades brasileiras. A quarta seção, apresenta uma análise do repertório confrontacional, em que se destacou a estrutura de oportunidades políticas que permitiu o desenvolvimento desse processo de ocupação urbana; apresenta também uma análise do protagonismo das mulheres na dinâmica confrontacional, cujo símbolo é centralidade da construção da creche comunitária na dinâmica confrontacional. Nesse sentido, conclui-se que os processos de ocupação representam para os movimentos sociais de luta por moradia um mecanismo de enquadramento interpretativo do problema da moradia, resultando em pressão política sobre os governos para que as demandas sejam atendidas. Contudo, esse elemento de repertório não se limita apenas a um mecanismo de pressão, pois, como argumentamos, a partir da contribuição da Teoria do Processo Político, a própria experiência de ocupação joga luz sobre possibilidades de desenvolvimento de novos repertórios que tenham como objetivo a disputa de narrativas sobre o direito à cidade e sua relação com o exercício da função social da propriedade urbana. Desse modo, a análise aqui apresentada se filia a uma agenda de pesquisa mais ampla sobre os movimentos sociais urbanos no contexto de inflexão ultraliberal (Santos Júnior, 2019).

Em termos metodológicos, o estudo de caso apresentado baseia-se em entrevistas com representantes do Movimento de Luta nos Bairros Vilas e Favelas (MLB) ${ }^{2}$ e moradores da vila Eliana Silva. Os entrevistados falam da história da Vila, da consolidação das ocupações urbanas de Belo Horizonte e da atuação dos movimentos sociais de luta pela moradia. As entrevistas foram realizadas em dois momentos com os mesmos representantes. Primeiramente, em fevereiro de 2016, quando da publicação do livro Participação, conflitos e intervenções urbanas: contribuições à Habitat III, publicado no contexto da Conferência das Nações Unidas sobre Habitação e Desenvolvimento Urbano Sustentável - Habitat III, e posteriormente, em novembro de 2018, logo após o pleito eleitoral e a divulgação da possibilidade de extinção do Ministério das Cidades.

\section{A construção da política habitacional de interesse social no Brasil}

A política de Habitação Social no Brasil tem sido edificada pela progressiva apropriação dos pressupostos do Direito à Cidade postulados pelo Movimento de Reforma Urbana e pelas Cartas das Nações Unidas sobre o assunto. ${ }^{3}$ 0 ponto central do debate acerca da moradia gira em torno do estabelecimento de um 
padrão de habitação cujo parâmetro não seja somente um teto. A casa, nesse sentido, seria entendida como o domicílio com grau aceitável de habitabilidade e que proporcionasse segurança da posse; e com disponibilidade de serviços urbanos, infraestrutura e equipamentos públicos a custo acessível. Para além desses fatores, seriam valorizados, ainda, as relações sociais e os vínculos estabelecidos entre os indivíduos e o território.

O padrão de política de habitação social implantado pelos Institutos de Aposentadoria e Pensões e pela Fundação da Casa Popular entre as décadas de 1930 e meados da década de 1960 pautou a política habitacional através do privilégio da produção de unidades habitacionais, sem a articulação com outras políticas urbanas.

Na década de 1960, na esteira de um acelerado processo de urbanização que então se consolidava, as grandes cidades brasileiras já se caracterizavam pela expansão das periferias urbanas, ocupadas por vilas, favelas e loteamentos populares - áreas precárias quanto às condições de infraestrutura urbana e fundiária, repetidas vezes sujeitas a ações violentas de despejo e remoção por parte do poder público.

Num cenário de ausência de políticas urbanas e habitacionais que possibilitassem o reconhecimento da cidade como um direito, bem como de agravamento dos problemas urbanos, aconteceu, no ano de 1963, o Seminário Nacional de Habitação e Reforma Urbana - conhecido como Seminário da Quitandinha, por ter sido realizado no Hotel Quitandinha, em Petrópolis/RJ. As resoluções do Seminário da Quitandinha consolidaram uma pauta de defesa da moradia digna e de uma cidade justa baseada na combinação da produção habitacional e de estratégias de acesso à terra urbanizada, a partir de processos de planejamento urbano baseados em zoneamentos especiais para habitação de interesse social e em promoção da regularização fundiária dos assentamentos precários. Contudo, com o golpe militar em 1964, a pauta da reforma urbana submerge sob o governo autoritário, e inaugura-se, a partir da criação do Sistema Nacional de Habitação - SNH, novo ciclo de política habitacional baseada na produção em massa de habitações para população de baixa renda, caracterizada pela localização periférica desprovida de cidade.

Apesar da ênfase na construção de grandes conjuntos habitacionais, ainda na década de 1970, observa-se certo grau de investimentos nos chamados "projetos alternativos" que reconheciam a importância dos processos de urbanização de favelas e de experiências autogestionárias. Grazia (2003) lembra que, nesse período, os movimentos sociais voltaram a reivindicar uma política urbana que integrasse questões referentes ao uso do solo e à problemática habitacional, pautando, assim, uma política mais coerente com os problemas das cidades brasileiras.

Em 1977, houve uma primeira tentativa de estabelecimento de um marco regulatório que criasse uma política nacional de desenvolvimento urbano. No início da década de 1980, em articulação feita através da Comissão Nacional de Desenvolvimento Urbano, a sociedade civil organizada negociou o projeto de lei $n$. 775/1983, que previa a criação de instrumentos urbanísticos que promovessem a implementação do princípio da função social da propriedade. Contudo, os diversos instrumentos 
de combate à especulação imobiliária dispostos nesse projeto de lei provocaram forte reação no Congresso e, consequentemente, não alcançou aprovação em plenário.

Apesar dessa primeira derrota, Souza (2003) enfatiza que as propostas defendidas no Seminário da Quitandinha em 1963 e sistematizadas no projeto de lei 775/1983 foram resgatadas na Assembleia Constituinte de 1987 e 1988, quando da apresentação de uma proposta de Emenda Constitucional de Iniciativa Popular. Nesse momento, com o apoio do setor técnico, os movimentos sociais organizaram-se em torno de uma proposta que preconizava o combate à retenção de imóveis ociosos, o estabelecimento da participação popular nos processos de construção das políticas urbanas, além de mecanismos de regularização fundiária dos assentamentos populares. A emenda constitucional de iniciativa popular resultou nos artigos 182 e 183 da Constituição Federal, os quais tratam da política urbana brasileira.

Embora a mobilização tenha conquistado êxito na garantia desses dois artigos no texto da Constituição Federal, a redação aprovada condicionou a aplicação dos instrumentos à criação de uma lei federal que os regulamentasse. Além disso, vinculou os instrumentos aos planos diretores municipais, impondo um filtro técnico aos anseios dos movimentos sociais urbanos. A falta de autoaplicabilidade dos artigos 182 e 183 levou a uma nova mobilização do Fórum Nacional de Reforma Urbana, o qual conseguiu assinaturas suficientes para protocolar a lei de iniciativa popular n. 5.788/1990 que, após onze anos de tramitação e de diversas modificações, deu origem ao Estatuto da Cidade (lei federal n. 10.257/2001).
Com o pacto federativo instituído pela Constituição Federal de 1988, identificou-se um forte processo de municipalização das políticas habitacionais, interrompendo o padrão das políticas desenvolvidas até então. Para os movimentos sociais, a descentralização da responsabilidade sobre as políticas urbanas colocava a população numa relação mais próxima aos espaços de decisão, podendo pautar de uma forma mais capilarizada as demandas por moradia.

Embora a municipalização gerasse uma expectativa de respostas objetivas e efetivas às problemáticas da cidade, a descentralização das políticas urbanas e habitacionais não veio acompanhada por uma repartição das receitas que financiariam essas políticas (Cardoso e Ribeiro, 2000). Nesse sentido, constatou-se que, para a grande parte das administrações locais, não havia capacidade administrativa para implementar ações relativas ao planejamento e à gestão territorial. A fragilidade institucional gerou reduzido grau de planejamento urbano nos municípios e baixa integração das políticas urbanas de saneamento, transporte, uso do solo e habitação. Como reflexo da inércia institucional, no que concerne às questões urbanas, entre 1986 e 2003, predominou a implantação de programas desconexos e com pouca perspectiva de continuidade em todos os níveis de governo.

Para lidar com a ineficiência das políticas urbana e habitacional, após a redemocratização, houve a proliferação de iniciativas protagonizadas pela sociedade civil organizada, com o intuito de gerar novas metodologias de trabalho e boas práticas que pudessem ser absorvidas pelas administrações locais. Essas práticas foram desenvolvidas à luz dos preceitos defendidos pelo Movimento 
de Reforma Urbana que usava de sua rede de articulação política para promoção e difusão dessas experiências.

O centro das reivindicações dos movimentos sociais girava em torno da gestão democrática das cidades, e as práticas que compunham o leque de políticas envolviam não somente novas metodologias de implantação de programas, mas propostas para estruturação organizacional das instituições, incorporando conselhos e implantação de processos participativos para a definição de dotações orçamentárias.

De uma forma geral, a questão urbana no âmbito do poder público entre as décadas de 1980 e 2000 foi influenciada pela pressão política exercida pelos movimentos sociais de moradia. Os municípios que consolidaram um escopo mais substancial de políticas e de desenvolvimento institucional na área foram também aqueles que tiveram que lidar com um movimento social mobilizado e ativo.

A partir de 2003, com o governo Lula, foi observada a tentativa, no âmbito federal, de consolidação de uma política urbana e habitacional incorporando as práticas propostas pelo movimento social e institucionalizadas a partir de experiências de governos locais progressistas. Dentro da reforma administrativa realizada no início do governo, foi criado o Ministério das Cidades. Pela primeira vez na história, um órgão, com status ministerial, iria abrigar secretarias de gestão das principais políticas urbanas: Habitação, Saneamento, Transporte e Planejamento. A junção dessas secretarias em um único ministério proporcionou o amadurecimento de ações articuladas. A Secretaria Nacional de Habitação procurou dar sequência ao "Projeto Moradia", concebido antes da campanha eleitoral, fruto de um projeto político resultante da experiência acumulada em política habitacional desenvolvida pelas administrações municipais do Partido dos Trabalhadores, somado a uma série de debates realizados junto à sociedade civil (Bonduki, 2008).

Considerando o debate acerca das atribuições de cada ente federado em relação à habitação, suscitado com a Constituição Federal de 1988, foi proposta a criação do Sistema Nacional de Habitação de Interesse Social (SNHIS). Esse novo sistema reforçava o papel estratégico das administrações locais e propunha a sua articulação institucional e financeira com outros níveis de governo. Para que os estados e municípios pudessem integrar o novo arranjo de planejamento e gestão da política habitacional, eles teriam de aderir à estrutura de criação de fundos, conselhos e planos locais de Habitação de Interesse Social (HIS). Esses institutos eram uma forma de garantir sustentabilidade, racionalidade e, sobretudo, a participação democrática na definição e implementação dos programas e projetos. Como elemento central do SNHIS, o Fundo Nacional de Habitação de Interesse Social (FNHIS), criado a partir de um projeto de lei de iniciativa popular, sob a liderança do movimento de moradia, permitiria o repasse de recursos a fundo perdido para estados e municípios, sendo estes os principais executores das políticas. ${ }^{4}$

A mudança que se opera na política econômica do governo a partir de 2006 é caracterizada por uma progressiva liberalização dos gastos públicos, sem romper completamente com a política anterior. Como reflexo, foi observada a priorização de uma agenda econômica ao passo que as questões sociais já teriam sido consideradas como estabelecidas 
na agenda. Nesse sentido, o Programa de Aceleração do Crescimento (PAC), lançado em 2007, torna-se emblemático da nova agenda governamental. ${ }^{5}$

Em 2009, uma inflexão no modelo de política habitacional estabeleceu-se com o lançamento do Programa Minha Casa Minha Vida (PMCMV): um programa de crédito imobiliário que visou financiar a aquisição de moradia para famílias com renda mensal de até 10 salários-mínimos. Vasta produção acadêmica demonstra que o lançamento do PMCMV foi feito à revelia dos debates realizados pelo SNHIS e das diretrizes definidas no Plano Nacional de Habitação - PlanHab (Royer, 2009; Ferreira, 2014; Rolnik, 2015).

Embora todos os avanços destacados até aquele momento tenham balizado experiências exitosas no planejamento e gestão das cidades, a inércia institucional e as disputas políticas entre os diversos agentes produtores do espaço não permitiram uma eficiência das políticas urbanas almejadas pelos movimentos de reforma urbana e direito à moradia. Dessa forma, para além do cenário institucional, os movimentos sociais continuaram exercendo importante papel de pressão política através das práticas de ocupação de terrenos que não estavam cumprindo função social, da difusão de metodologias e da implantação de novas práticas urbanas como a autoconstrução. Além disso, intelectuais e associações profissionais permaneceram refletindo sobre os gargalos políticos e sobre novas alternativas de atuação.

\section{Os dilemas e possibilidades de repertório de ação para os movimentos de moradia no contexto da inflexão ultraliberal}

Em novembro de 2018, após uma disputa eleitoral atípica para a Presidência da República, Jair Bolsonaro (PSL) foi eleito com $55,1 \%$ dos votos válidos, contra $44,9 \%$ de Fernando Haddad (PT). Essa disputa eleitoral marcou o fim de um ciclo de estabilização da competição presidencial entre PT e PSDB, que vigorava desde 1994. Jair Bolsonaro, ao longo de sua campanha, evitou a abordagem direta de temas que demonstrava pouco conhecimento, delegando a tarefa para integrantes de sua equipe, como, no caso das questões econômicas, que eram respondidas pelo economista Paulo Guedes, a quem já havia prometido um ministério no futuro governo. Além disso, buscou compensar o pequeno tempo de campanha em televisão com uma comunicação que explorou o uso da internet e de aplicativos de comunicação, por meio dos quais manifestava mais diretamente os seus posicionamentos sobre diversos temas considerados relevantes para o seu eleitorado, como segurança pública e combate à corrupção, além da difusão de notícias inverídicas sobre seus adversários, as chamadas fake news. 
Especificamente em relação ao tema das políticas urbanas, Bolsonaro não apresentou qualquer proposta, seja em seu programa de governo, seja durante a campanha eleitoral, que fosse além das críticas genéricas a iniciativas de governos anteriores do Partido dos Trabalhadores, como o Programa Minha Casa Minha Vida. No entanto, ganhou relevância, no seu discurso, a retórica de enfrentamento aos movimentos sociais, por considerá-los uma ameaça a ser combatida. Em seu plano de governo, consta claramente a proposta de tipificação como "terrorismo" das ocupações de propriedades rurais ou urbanas (Baratto, 2018). Essa proposta, ao buscar criminalizar um dos repertórios utilizados por movimentos sociais urbanos e rurais, traz consigo o não reconhecimento da importância das demandas e reivindicações de diversos movimentos sociais, assim como a previsão de pouca abertura ao diálogo com a sociedade civil organizada.

Além da ausência de propostas concretas para áreas específicas das políticas urbanas (Saneamento, Habitação, Mobilidade e Desenvolvimento Urbano), Bolsonaro mencionou a intenção de extinguir o Ministério das Cidades, utilizando-se como argumento que o governo federal repasse direto os recursos para as prefeituras, sem intermediação da pasta (Frazão, 2018). Por fim, na montagem do gabinete ministerial dada pela medida provisória n. 870/2019, o Ministério das Cidades foi extinto, tendo a sua estrutura fundida com o Ministério da Integração Nacional, dando lugar ao novo Ministério do Desenvolvimento Regional. ${ }^{6}$

0 vazio de propostas para a temática do desenvolvimento urbano complementa-se com a incompreensão da importância da criação do Ministério das Cidades para a formulação e implementação de uma política urbana em nível nacional. Portanto, além de ignorar que o diálogo direto com os entes municipais já era uma atividade desenvolvida pelo MCidades, ${ }^{7}$ a proposta apresentada pelo novo governo na condução das políticas e programas no interior do novo ministério também ignorou que não bastava o repasse direto de recursos sem que esse repasse estivesse atrelado a ações de desenvolvimento institucional para a implementação de programas e políticas em prol do desenvolvimento urbano. Ademais, fica a preocupação sobre como os municípios farão o enfrentamento desses problemas num contexto de crise econômica com reflexos em sua capacidade fiscal, já que a existência de uma pasta ministerial própria para a temática do desenvolvimento urbano também é importante para a garantia da condição de barganha de recursos e de posição na agenda governamental em relação aos interesses de outras pastas.

Ainda no bojo da discussão sobre o impacto da extinção do Ministério das Cidades, considera-se como inegáveis os avanços institucionais ocorridos no período da sua existência, organizados aqui em dois aspectos. O primeiro foi a consolidação de um marco jurídico urbanístico que permitisse a regulação das políticas setoriais que compunham o rol de atuação do extinto ministério, como: (1) na área de habitação e regularização fundiária (lei n. 11.124/2005; decreto n. 5.796/2006; lei n. 11.481/2007; lei n. 11.952/2009; lei n. 11.977/2009; lei n. 13.465/2017); na área de saneamento, incluindo a configuração da Política Nacional de Resíduos Sólidos (lei n. 11.445/2007; decreto n. 7.217/2010; lei n. 12.305/2010; decreto n. 7.404/2010); na área de transportes, com 
a configuração da Política Nacional de Mobilidade Urbana (lei n. 12.587/2012); a instituição da Política Nacional de Proteção e Defesa Civil (lei n. 12.608/2012); e a instituição do Estatuto da Metrópole (lei n. 13.089/2015). O segundo foi a instituição do Conselho das Cidades ConCidades (decreto n. 5.031/2004, posteriormente substituído pelo decreto n. 5.790/2006), como órgão colegiado, de natureza deliberativa e consultiva, ligado diretamente ao ministério, e tendo como finalidade a proposição de diretrizes para a formulação e implementação da Política Nacional de Desenvolvimento Urbano, assim como o seu acompanhamento e avaliação após implementação.

Importante lembrar que a instituição do Conselho das Cidades buscou efetivar o disposto no art. 43 do Estatuto das Cidades (lei federal n. 10.257/2001). A existência do ConCidades, com a realização de conferências nacionais em que é assegurada a participação da iniciativa privada, dos governos municipais e estaduais e da sociedade civil, é elemento central na garantia de uma gestão democrática das cidades. Sendo assim, tanto a extinção do ministério quanto a proposta de criminalização dos movimentos sociais configuram-se como um risco direto para a concretização dessa gestão democrática na condução da política nacional de desenvolvimento urbano, especialmente por trazerem consigo o afastamento da sociedade civil organizada da esfera decisória no campo das políticas urbanas.

Antes de discorrer especificamente sobre o repertório de ação por meio das ocupações urbanas, é necessário contextualizar o campo da luta por moradia no Brasil. Segundo Ferreira (2014, p. 83), os movimentos sociais de luta pela moradia estão organizados em quatro grandes federações de associações: a Confederação Nacional das Associações de Moradores (Conam), a Central dos Movimentos Populares (CMP), o Movimento Nacional de Luta pela Moradia (MNLM) e a União Nacional por Moradia Popular (UNMP). Esses quatro grandes movimentos estão organizados nacionalmente, tendo surgido ao longo das décadas de 1980 e 1990, a partir de diferentes contextos. De certa forma, o surgimento e a organização de cada um desses movimentos consolidaram repertórios de ação diferenciados, que buscam responder de formas variadas aos estímulos de determinado contexto político. ${ }^{8}$

Dentre a gama de temas a partir dos quais se dão as mobilizações em torno da questão da moradia, podemos citar: (1) a luta contra os despejos e remoções; (2) a regularização fundiária; (3) a melhoria habitacional; e (4) a produção de habitação de interesse social. Essa gama de temas busca ser respondida a partir de ações coletivas que configuram o repertório de ação dos movimentos. Esse repertório pode ser organizado da seguinte forma:

O movimento de moradia desenvolveu ao longo da experiência de interação conflitiva com o Estado um conjunto de práticas e rotinas que conformaram um repertório de ação no qual se destacam como estratégias principais, embora não exclusivas: 1) a ocupação de prédios e terrenos públicos; 2) a participação em espaços institucionais; 3 ) a luta por moradia no centro; e 4) a construção por mutirão autogestionário. (Tatagiba, Paterniani e Trindade, 2012, p. 401)

Assim como proposto em Tatagiba, Paterniani e Trindade (ibid.), fazemos referência ao conceito de repertórios de ação coletiva, tal como formulado na Teoria do Processo Político (também conhecida como Teoria da Mobilização Política), ${ }^{9}$ representada pelos trabalhos 
de McAdam, Tarrow e Tilly (2009). Numa definição bastante sucinta, podemos considerar os repertórios de ação como um "campo limitado de rotinas que são aprendidas, compartilhadas e executadas através de um processo relativamente deliberado de escolha" (Tilly, 1995, p. 26). Segundo Alonso (2012, p. 22), o conceito de repertório, ao buscar relacionar a cultura com o conflito político, destacou a lentidão das mudanças culturais, deixando, porém, margem para os agentes exercerem suas escolhas de acordo com a volatilidade das conjunturas políticas. Dizendo de outra maneira, o repertório dessas escolhas é definido a partir de uma estrutura de oportunidades que se configura num dado momento histórico. Portanto, a historicidade contida nessa definição permite conciliar tanto a rotinização das práticas, quanto a adição ou subtração de formas de ação de acordo com o seu sucesso ou fracasso em uma dada conjuntura. Ou seja, estrutura e agência permanecem equilibradas a partir da liberdade de escolha da execução do repertório de modo estratégico e na interação entre as partes de um conflito. Sendo assim, os sentidos das ações são produzidos de maneira recíproca entre os detentores do poder e os seus desafiantes. ${ }^{10}$

Segundo Moreira (2009 apud Ferreira, 2014, p. 88), as ocupações coletivas são a principal estratégia dos movimentos para viabilizar, junto aos governos municipais e estaduais, a desapropriação de terras e o acesso a financiamento que permita a construção de moradias. Portanto, a base para esse tipo de ação está na concretização do princípio da função social da propriedade, tal como exposto na Constituição Federal de 1988 em seu artigo 5으, inciso XXII, no qual afirma que a todos é garantido o direito de propriedade. No entanto, no inciso XXIII, o direito à propriedade é relativizado, pois está submetido ao atendimento de sua função social. O reconhecimento da necessidade de função social como complemento indissociável ao direito subjetivo à propriedade busca responder às transformações sociais processadas ao longo do tempo que desafiam a concepção doutrinária individualista do direito à propriedade, submetendo-o a uma concepção coletivista em que a convivência em sociedade demanda que as ações individuais contribuam para o bem-estar de uma coletividade.

Portanto, as ocupações são uma importante forma de ação coletiva na luta por acesso à moradia ao provocarem o poder público para agir em consonância com a prevalência da função social da propriedade sobre o direito de propriedade visto como algo absoluto. Desse modo, na experiência de ocupação nem sempre o objetivo é a desapropriação do imóvel ou terreno ocupado, mas, em todos os casos, o objetivo é dar visibilidade à demanda por moradia por meio de uma modalidade de ação que é disruptiva por natureza. Logo, a criminalização da prática das ocupações proposta pelo governo Bolsonaro representou interferência direta no repertório de ações coletivas consolidado ao longo da experiência dos movimentos de moradia.

A fim de compensar o veto a essa forma de ação coletiva, restaria, aos movimentos, a sua atuação nos espaços de participação e deliberação democrática das políticas urbanas que foram sendo implementados ao longo da última década. No entanto, a extinção do Ministério das Cidades, conforme dito anteriormente, coloca em xeque a consolidação de um Sistema Nacional de Desenvolvimento Urbano, segundo o qual a ocorrência de conselhos participativos e deliberativos nas três esferas 
de governo permitiria uma ampliação dos canais de participação dos movimentos sociais de moradia na definição das políticas de desenvolvimento urbano nos diferentes níveis. ${ }^{11}$ Dessa maneira, argumenta-se que a extinção do Ministério das Cidades proporcionou uma significativa alteração na estrutura de oportunidades para a ação política, o que significou a necessidade de uma modificação no repertório de ação dos movimentos de moradia.

Não há como definir a priori se as ocupações deixarão de fazer parte do repertório dos movimentos, principalmente porque hoje eles já enfrentam resistência para a sua legitimação na sociedade; e, também, porque não contam com uma disposição favorável na maioria dos órgãos governamentais. Esta tem sido a luta cotidiana dos movimentos urbanos, especialmente daqueles que optam por ações disruptivas, num confronto mais direto com o status quo da distribuição de poder nas cidades. Por conseguinte, ressalta-se, novamente, a importância dos aspectos histórico e relacional do conceito de repertório, já que os contextos de mudança são propícios a inovações (ou ressignificações) nas formas de ação ancoradas nos desafios cotidianos marcados por performances confrontacionais com os detentores do poder.

Disso decorre que uma possibilidade de atuação dos movimentos de luta por moradia no contexto do novo governo está na disputa pelo enquadramento (framing) de suas demandas. ${ }^{12}$ Segundo Klandermans (1997, p. 44 apud Tarrow, 2009, p. 143), "a transformação de questões sociais em quadros interpretativos da ação coletiva não ocorre por si própria. É um processo em que os atores sociais, a mídia e os membros de uma sociedade interpretam, definem e redefinem a situação conjuntamente". De acordo com Tarrow (2009, p. 144), faz parte da conduta dos movimentos sociais a tarefa de "nomear" os seus descontentamentos (em conexão com outros), a fim de construir um quadro de significados que faça sentido para as predisposições culturais de uma sociedade, processo que é chamado, por Snow (1986 apud Tarrow, 2009, p. 144), de alinhamento dos quadros interpretativos. No entanto, essa não é uma tarefa fácil, porque:

\footnotetext{
Primeiro, os líderes dos movimentos competem com outros movimentos, com os agentes da mídia e com o Estado pela supremacia cultural - competidores que têm recursos culturais imensamente poderosos à sua disposição. Segundo, os movimentos que se adaptam bem demais às culturas de suas sociedades perdem o poder de oposição e alienam seus apoiadores mais militantes - pois qual é a sociedade cujos valores dominantes não apoiam os arranjos de poder existentes? Terceiro, as pessoas comuns fazem frequentemente a sua própria "leitura" dos acontecimentos, que difere daquelas feitas por seus líderes e frequentemente assimila a interpretação que as elites dão a seus fracassos. (Tarrow, 2009, p. 144)
}

Por fim, a tarefa de disputar o enquadramento em torno da mobilização de um quadro interpretativo da injustiça (ibid.) configura-se como um desafio especial na atual conjuntura sociopolítica no Brasil em que dois aspectos se sobressaem, numa atuação combinada durante o processo eleitoral de 2018: (1) a mobilização de elementos de um conservadorismo social pouco (ou anti) democrático (Cruz, Kaysel e Codas, 2015; Solano, 2018); e (2) a utilização de mídias digitais e aplicativos de comunicação direta por mensagens como meios de construção de uma narrativa em que os movimentos sociais são vistos como uma ameaça para esses valores sociais conservadores (Carvalho, 
2020; Recuero e Gruzd, 2019). Para cumprir esse objetivo, foram empregadas, como recursos, tanto a utilização em massa das chamadas fake news, quanto a construção de uma suspeição em torno dos veículos de comunicação tradicionais. Dentre os elementos valorativos mobilizados nessa empreitada neoconservadora e ultraliberal, estão valores como liberdade individual, garantia da propriedade e segurança. Portanto, o segredo do sucesso dessa empreitada está na manipulação de um segmento significativo da opinião pública com relação à imagem transmitida por ações coletivas disruptivas da ordem social vigente como as ocupações.

Disputar essa construção interativa de significados em confronto direto com os agentes da mídia e o Estado - detentores do poder de agendamento (agenda-setting) no atual contexto - parece ser tarefa primordial dos movimentos de luta por moradia nesse novo contexto, pois coloca a necessidade de uma reflexão ainda mais estratégica sobre as práticas tradicionais que compõem o seu repertório de ação coletiva, especialmente dos movimentos de moradia que utilizam a ocupação de terrenos sem função social como elemento central do seu repertório de ação confrontacional.

0 estudo de caso sobre o processo de ocupação e consolidação da vila Eliana Silva em Belo Horizonte, que será apresentado na próxima seção, permitirá a exploração de elementos do repertório confrontacional dos movimentos de luta por moradia que possuem a ocupação de terrenos vazios ou subutilizados como a sua estratégia central.

\section{O histórico da vila Eliana Silva e a dinâmica do confronto político}

A história da vila Eliana Silva começa com a luta pelo direito à moradia de diversas famílias da Região Metropolitana de Belo Horizonte (RMBH) que não tinham onde morar. Duzentas e noventa e oito ${ }^{13}$ famílias organizadas pelo Movimento de Luta nos Bairros, Vilas e Favelas (MLB) ocuparam, em abril de 2012, um terreno pertencente à prefeitura de Belo Horizonte (PBH), situado na região do Barreiro, na capital mineira. Esse local foi chamado pelos entrevistados de primeira Ocupação Eliana Silva.

Apesar da mobilização, as famílias sofreram uma ação de despejo 21 dias após o início da ocupação. Alguns meses depois, em agosto de 2012, as famílias ocuparam o terreno onde hoje está a vila Eliana Silva. Segundo os entrevistados, no dia em que aconteceu o despejo das famílias da primeira Ocupação Eliana Silva, a então presidenta Dilma Rousseff estava em Betim, na Região Metropolitana de Belo Horizonte, acompanhada pelo prefeito de Belo Horizonte, para a entrega de um empreendimento executado através do Programa Minha Casa Minha Vida. ${ }^{14}$ Alguns coordenadores da ocupação e representantes do MLB seguiram para o local do evento com uma carta escrita pelos moradores em busca de uma tentativa de negociação. A negociação não aconteceu e também não foram apresentadas, por parte do poder público, alternativas de reassentamento ou abrigo para as famílias. 
A PMMG cercou o terreno ocupado, e a ação de despejo iniciada numa sexta-feira durou cerca de 24 horas. ${ }^{15}$ Durante a ação, foi proibida a entrada de pessoas com alimento no interior da ocupação, e equipamentos como geladeiras e fogões foram recolhidos. A despeito da ação de despejo em curso, boa parte das famílias ainda estava disposta a resistir e não queria deixar o terreno. No entanto, as lideranças da ocupação, numa avaliação coletiva com as famílias e apoiadores que se encontravam no terreno, optaram pela desocupação. Apesar da tristeza das famílias, os entrevistados afirmam que a desocupação do terreno não enfraqueceu a luta pelo direito à moradia, pelo contrário, em suas palavras, o sentimento era de que amanhã vai ser maior. ${ }^{16}$ E foi!

A segunda ocupação da comunidade Eliana Silva aconteceu 3 meses após a ação de despejo da primeira. Durante esse período, as famílias que ocuparam, na primeira tentativa, ficaram alojadas num local cedido pela Igreja. Os entrevistados relataram: passamos o Dia das Mães chorando o despejo, comemorando o Dia das Mães e sonhando com o outro dia. ${ }^{17}$ Ainda contaram que, na primeira reunião realizada após o despejo, estavam presentes mais de 300 famílias. Outros relatos da entrevista afirmaram que esse período foi importante para o fortalecimento das famílias e para a organização da nova ocupação, concluindo: e aí a gente fez a Eliana Silva.

A frase, dita com um sorriso no rosto dos entrevistados, traduz o protagonismo dos movimentos sociais e das famílias em face da luta pelo direito à moradia. 0 terreno que hoje abriga a vila Eliana Silva foi ocupado no dia 22 de agosto de 2012 e, segundo relato dos entrevistados, novo cerco da PM foi montado, permanecendo no terreno por 24 horas.

Figuras 1 e 2 - Ação de despejo da primeira Eliana Silva em 11/5/2012
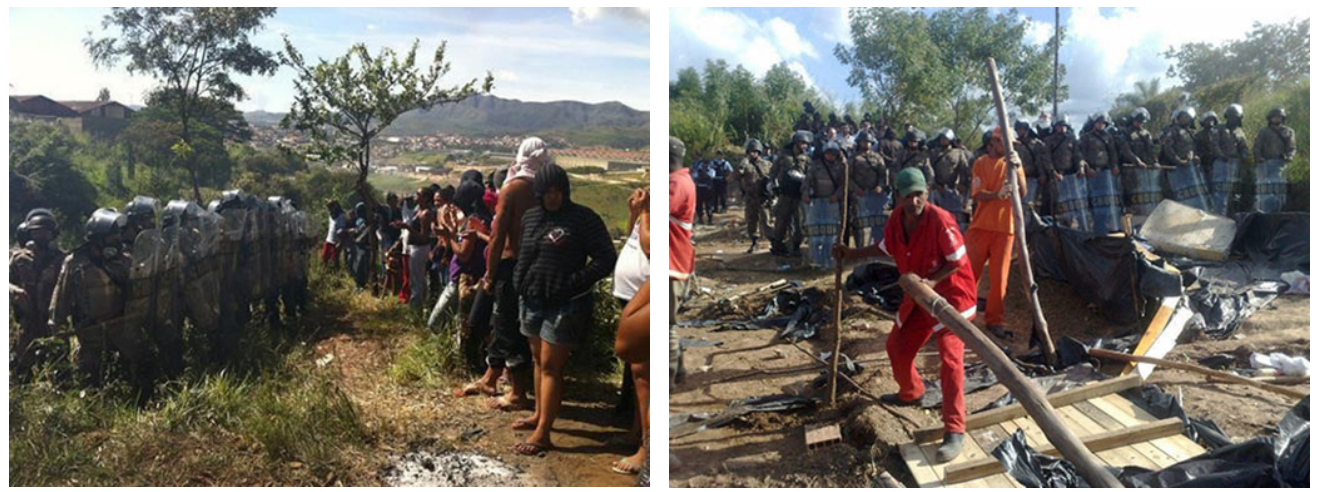

Fonte: arquivo Movimento de Luta nos Bairros, Vilas e Favelas (MLB). 
Diferentemente do que havia ocorrido na primeira ocupação, o despejo não foi executado. Foi colocada em prática uma tentativa de inviabilizar a permanência das famílias no terreno ocupado, por meio de ações violentas no seu entorno e de estratégias que dificultavam o acesso das famílias à água, à energia elétrica e à alimentação. Com a colaboração dos movimentos sociais organizados e de diversos grupos de apoiadores, as famílias resistiram e, 2 meses após o início da ocupação, já se encontravam construídos 100 barracos em alvenaria.

Assim como havia acontecido na primeira ocupação, as primeiras estruturas a serem erguidas foram a Creche Tia Carminha e a cozinha comunitária. Apesar de consolidada, a ocupação sofreu sucessivas tentativas de corte da energia elétrica. Além disso, a ausência de um endereço oficial e o não reconhecimento da legitimidade da ocupação por parte do poder público trouxeram uma série de dificuldades às famílias quanto ao acesso aos serviços básicos de saneamento, bem como ao atendimento nos postos de saúde mais próximos.

A negação da legitimidade do repertório confrontacional, por parte das autoridades públicas, tende a reforçar ainda mais a dinâmica do confronto, pois a experiência cotidiana à margem dos direitos sociais consolidados aumenta ainda mais a importância dos termos da

Figura 3 - Localização da vila Eliana Silva

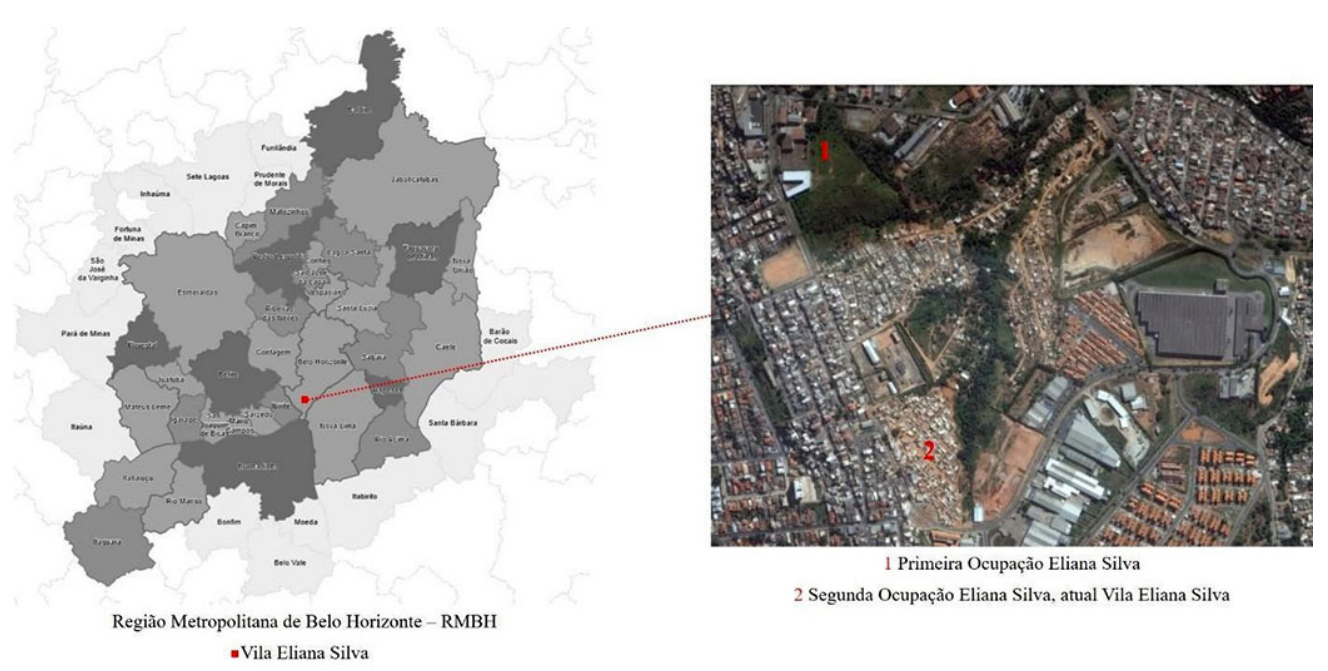

Nota: em destaque, no mapa à esquerda, a inserção da vila Eliana Silva na RMBH e, na vista aérea à direita, a localização do terreno onde ocorreu a primeira ocupação Eliana Silva (1) e a área onde ocorreu a segunda ocupação Eliana Silva, atual vila Eliana Silva (2).

Fonte: elaborado pelos autores, em 2018. 
disputa por terra urbana como demanda coletiva. Indo um pouco além, pode-se dizer que essa contradição contém os elementos fundamentais de uma disputa prática pela constituição de uma noção de comum, nos moldes colocados por Dardot e Laval (2017). Para esses autores, nada pode ser considerado comum na sua essência, mas como resultado das práticas coletivas (ibid., p. 618).

Contudo, os entrevistados apontam que a estratégia de resistência territorial também englobava tática de articulação política que não ficasse restrita às ações específicas das famílias. 0 primeiro passo foi a articulação dentro do próprio movimento de luta por moradia, a partir do entendimento de que o reconhecimento da legitimidade das ocupações ganha força com a existência de outras experiências promovidas por movimentos análogos na região. Nesse sentido, o vínculo com outros movimentos organizados adquire grande importância na negociação política com instituições do Estado - tanto em relação ao Poder Executivo, quanto em relação ao Poder Judiciário. Ou seja, as demandas em torno do reconhecimento do direito à moradia são sistematicamente postas como uma realidade possível à luz dos resultados obtidos por outros grupos na rede de articulação.

Os entrevistados ressaltaram, ainda, 0 papel do que eles chamam de "apoiadores de segunda ordem", na qual estão inseridos grupos da sociedade civil organizada e a própria Universidade. Quando do planejamento da segunda ocupação, o MLB buscou o apoio de alunos e professores da Escola de Arquitetura e Design da Universidade Federal de Minas Gerais (EAD-UFMG). Na época, um projeto de parcelamento do solo foi elaborado, contendo o arruamento, a definição de áreas de proteção ambiental e de uso coletivo, além da definição dos 298 lotes que hoje abrigam as famílias que integram a vila Eliana Silva.

Outro elemento importante para compreendermos a dinâmica do confronto em torno dessa ocupação urbana é o ciclo de protestos de junho de 2013. Segundo os entrevistados, a articulação de apoiadores foi fortalecida durante os protestos que tomaram as ruas das principais cidades do País no mesmo período de realização da Copa das Confederações. As massivas manifestações de rua foram iniciadas com a pauta das tarifas do transporte público e foram sendo ampliadas, no decorrer do ciclo, passando a contemplar pautas diversas e difusas. 0 ciclo de protestos apresentou mudanças de etapas importantes, que tiveram a ver com a disputa sobre o enquadramento dos objetivos dos protestos (Tatagiba, 2014). Internamente, grupos distintos enxergavam a mobilização como uma oportunidade de chamar a atenção para as suas pautas, inclusive de movimentos conservadores, que utilizaram a pauta anticorrupção como forma de capturar atenção da cobertura midiática (Silva, 2018). No entanto, a partir de uma leitura crítica, é possível capturar a expressão de demandas urbanas mal resolvidas, em meio à essa pluralidade de agendas, dentre as quais, o direito à moradia (Maricato et al., 2013). Assim como ocorreu em outros municípios, especialmente nas capitais, ganhou forma, em Belo Horizonte, a chamada Assembleia Popular Horizontal (APH). Dentre os grupos de trabalho (GT) que integravam a APH, estava o GT Reforma Urbana. As manifestações de rua na capital mineira resultaram na ocupação da câmara de vereadores e, posteriormente, a ocupação da prefeitura de Belo Horizonte. 
Os entrevistados contam que, durante uma seção da $\mathrm{APH}$, realizada durante a ocupação da câmara de vereadores, um deles foi eleito para compor a comissão que se reuniria com o governador de Minas Gerais e com o prefeito de Belo Horizonte, representando, nessa comissão, a pauta do direito à moradia $\mathrm{e}$ da regularização das ocupações urbanas.

Na época, várias ocupações urbanas situadas em Belo Horizonte e em outros municípios da RMBH encontravam-se em risco iminente de despejo. Para demonstrar a força da mobilização, após a desocupação da câmara de vereadores, o hall do prédio da $\mathrm{PBH}$ e o gabinete do prefeito foram ocupados por moradores da vila Eliana Silva e diversos apoiadores das ocupações urbanas - militantes de movimentos de luta por moradia com articulação em Belo Horizonte, alunos e professores do curso de Arquitetura e Urbanismo da EAD-UFMG, representantes do GT Reforma Urbana da APH, dentre outros. A ocupação da PBH durou dois dias, terminado com a promessa de suspensão temporária das ações de despejo.

Pouco mais de um ano após a truculenta ação de despejo contra as famílias da primeira ocupação Eliana Silva, foi aberta mesa de negociação com o governo do estado e a $\mathrm{PBH}$, composta também por representantes das universidades e dos movimentos sociais. 0 objetivo foi discutir a regularização das ocupações urbanas em Belo Horizonte e na RMBH. A primeira conquista foi a suspensão das ações de despejo de pelo menos 5 ocupações urbanas de Belo Horizonte - Eliana Silva, Dandara, Irmã Dorothy, Camilo Torres e a recém-nascida Rosa Leão. ${ }^{18}$

Figuras 4 e 5 - Ocupação da PBH em julho de 2013
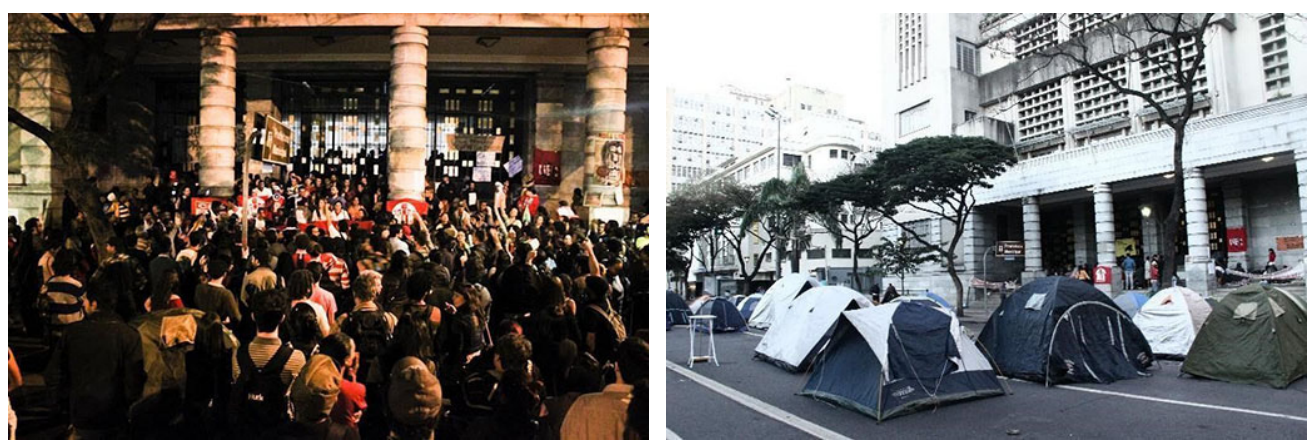

Fonte: arquivo Movimento de Luta nos Bairros, Vilas e Favelas. 
Os entrevistados ressaltam a importância das Jornadas de Junho de 2013 para o fortalecimento das reivindicações pelo direito à moradia através da unificação das lutas das ocupações urbanas. Isso porque, até aquele momento, a luta era pela suspensão das ações de despejo e, a partir de então, passou a incluir a regularização urbanística e fundiária das ocupações urbanas.

No que se refere à ocupação Eliana Silva, além da regularização do abastecimento de água, os entrevistados destacam as mobilizações pela regularização do serviço de fornecimento de energia elétrica e de esgotamento sanitário. Ressaltam, ainda, a participação do MLB na Conferência de Política Urbana de Belo Horizonte, que trata da revisão do Plano Diretor e da Legislação Urbanística Básica municipal. Durante a conferência, foi aprovada a transformação da área ocupada em Área de Especial Interesse Social (Aeis), cujo objetivo é garantir a realização de ações que visam à sua regularização fundiária. ${ }^{19}$ Para os entrevistados, apesar da morosidade e das decisões contrárias que permeiam o processo judicial de reintegração de posse do terreno ocupado, a regularização da vila Eliana Silva, como das outras ocupações urbanas, deve considerar primeiro a sua consolidação, a conquista dos direitos aos serviços básicos de saneamento, saúde e educação e, por fim, a questão fundiária, no caminho inverso dos processos de regularização coordenados pelo poder público.

Ao resgatarmos a fala dos entrevistados durante a entrevista realizada em fevereiro de 2018, destacamos duas conquistas recentes das ocupações urbanas da RMBH que contribuem para a compreensão da importância da ação dos movimentos de luta por moradia para a construção de um arcabouço institucional permeável às demandas colocadas pelos movimentos. Na ocasião, foi mencionada a atuação do MLB junto à mesa de negociação com o Estado estabelecida em 2013 e durante a 4ạ Conferência Municipal de Política Urbana de Belo Horizonte, realizada em 2014.

Em 2015, foi instituída a Mesa de Diálogo e Negociação Permanente com Ocupações Urbanas e Rurais, através do decreto NE n. 203, de 1ㅇ de julho de 2015. Desde então, diversas ações de regularização e despejo de áreas ocupadas por famílias de baixa renda em todo o estado foram analisadas. Em 2018, após cinco anos de disputas e diversas manifestações reprimidas violentamente, foi suspensa definitivamente a ação de despejo de parte das ocupações Rosa Leão, Esperança e Vitória e firmado o compromisso de regularização urbanística e fundiária da área. ${ }^{20}$

Numa entrevista mais recente, realizada logo após o pleito eleitoral de 2018, os entrevistados lamentaram o anúncio da extinção do Ministério das Cidades, apesar do reconhecimento das diversas falhas institucionais e da limitação da atuação, especialmente no que se referia à resolução de conflitos fundiários. Os entrevistados ressaltaram que a criação do MCidades foi uma conquista dos movimentos de luta pela reforma urbana e que, mesmo diante da atuação institucional limitada, foram realizadas negociações importantes junto ao órgão, e sua extinção significaria um retrocesso para a agenda do direito à moradia. $\mathrm{E}$, diante de uma perspectiva de retrocessos nas políticas sociais, em geral, e de relações menos amistosas entre o governo federal e os movimentos sociais, os entrevistados apontam que o respeito à ordem institucional estabelecida através da promulgação da Constituição Cidadã de 1988 deve ser constantemente defendida. 
Figura 6 - Mobilização em frente à câmara municipal de Belo Horizonte: votação em primeiro turno do projeto de lei n. 1.479/2015

(Plano Diretor) no dia 20/11/2018

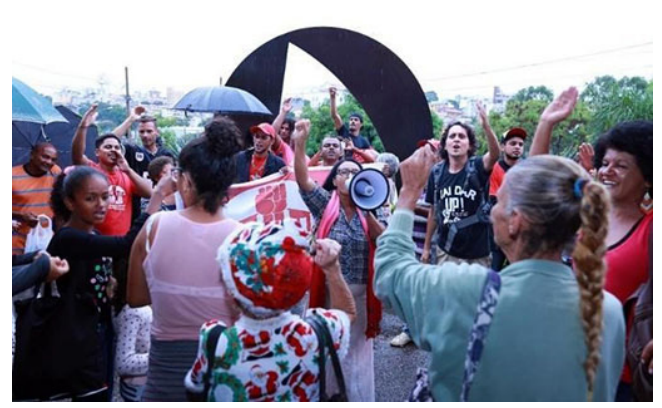

Fonte: https://www.flickr.com/photos/camarabh/

\section{Uma análise do repertório confrontacional}

Apesar dos avanços institucionais e políticos alcançados após a Constituição de 1988, conforme relatamos na primeira seção deste artigo, o mercado formal/legal de moradia não se tornou acessível à população mais pobre. Além disso, as políticas públicas de habitação se mostraram insuficientes para sanar as demandas históricas pelo direito à moradia digna.

Para Abramo (2007), a ocupação popular de terras urbanas é impulsionada, ainda no início do século XX, pela lógica da necessidade e transforma-se, a partir dos anos 1950, na principal forma de acesso da população de baixa renda ao solo urbano em muitos países latino-americanos, sendo, no Brasil, acirrada pelo próprio processo de urbanização. Ao analisar a constituição do mercado informal de moradia, especialmente nas periferias das grandes
Figura 7 - Plenário da câmara municipal de Belo Horizonte: votação em primeiro turno do projeto de lei n. 1.479/2015

(Plano Diretor) no dia 20/11/2018

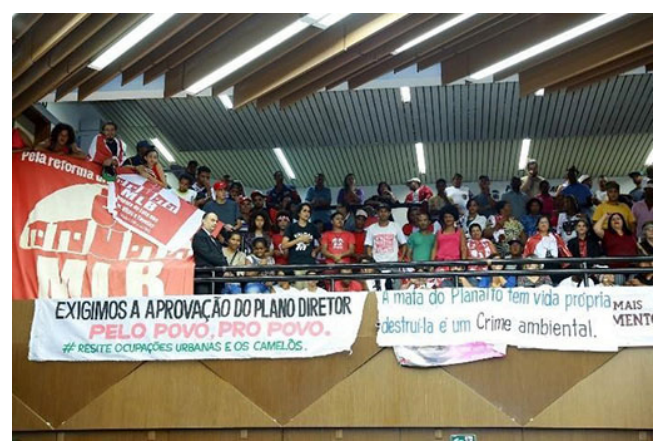

Fonte: https://www.flickr.com/photos/camarabh/

cidades latino-americanas, o autor afirma que o modelo de cidade formal modernista reproduzido pelas elites latino- americanas e estruturado sobre um conjunto de requisitos normativos contribuiu para a exclusão da população de baixa renda do mercado formal/ legal de moradia, especialmente das famílias com rendimento inferior a 3 salários-mínimos, induzindo a produção de moradia através da ocupação irregular e/ou clandestina (ibid.). Dessa forma, a população excluída do mercado formal/legal de moradia "apela para seus próprios recursos e produz moradia como pode" (Maricato, 2008, p. 44).

Essa corrente interpretativa, resumida por Abramo (2007), contextualiza e inscreve a ocupação dita irregular ou informal do espaço urbano numa dinâmica capitalista periférica de produção do espaço. Do ponto de vista das teorias de movimentos sociais, as expressões coletivas das demandas constituídas em torno da disputa pelo espaço urbano se organizam 
em torno dos chamados movimentos sociais urbanos. Esses movimentos trazem consigo uma leitura sobre o caráter desigual, do ponto de vista territorial, das condições sociais de (re)produção do espaço urbano sujeitas à lógica do processo de acumulação do capital. ${ }^{21}$ Essas teorias, em geral, fornecem um ferramental importante para a compreensão do conflito social que se expressa diretamente nas ações coletivas; contudo, destacamos aqui as contribuições possíveis, a partir da chamada Teoria do Processo Político. Dentre essas contribuições, destacam-se a possibilidade de uma leitura mais evidente sobre estrutura de oportunidades políticas em que as ocupações urbanas de fato ocorrem, para além da leitura sobre o conflito mais amplo sobre a produção capitalista do espaço urbano, e elementos relevantes que sustentam esse repertório confrontacional das ocupações urbanas como importante para os avanços nas demandas do movimento de luta por moradia. Destacando-se, especialmente, o protagonismo das muIheres na dinâmica confrontacional e a creche comunitária representando um elemento central no repertório de ação coletiva ao simbolizar a necessidade de construção comum das condições de luta numa perspectiva feminina reiteradamente ignorada no planejamento urbano tradicional.

\section{A estrutura de oportunidades políticas}

Apesar de tratar-se de um contexto caracterizado pela existência de programas estruturados de urbanização de favelas e de produção habitacional na esfera federal e municipal, a percepção dos integrantes do movimento que coordenou a ocupação da vila Eliana Silva era de que as políticas não conseguiram atingi-los. Com isso, para garantir seus direitos à moradia, era necessário ocupar espaços urbanos ociosos que poderiam servir de lar para as famílias desabrigadas. De certo modo, essa constatação por parte das lideranças dos movimentos aponta os avanços em termos das políticas habitacionais, apesar de uma postura crítica às suas limitações, destaca um contexto favorável à adoção das ocupações como um repertório confrontacional, buscando, a partir da própria experiência de ocupação, um outro enquadramento sobre a questão habitacional, evidenciando aspectos negligenciados pela agenda política até então.

0 direito à moradia não se limita ao abrigo, mas deve ser compreendido como o exercício do próprio direito à cidade. 0 reconhecimento dessa conquista na fala dos entrevistados explicita qualquer tentativa, conceitual ou não, de explicar a limitação das políticas públicas de habitação em face das lutas urbanas. Enquanto no âmbito institucional a política habitacional resumida ao Programa Minha Casa Minha Vida conferia, ao mercado imobiliário, o protagonismo das ações, nas ocupações urbanas, as famílias são os agentes produtores do espaço. São eles que respondem pelo seu direito à moradia e produzem a cidade tal qual seus desejos, necessidades e possibilidades. E, nessa performance cotidiana, desafiam a lógica hegemônica de produção do espaço urbano como espaço privado passível de ser transformado em ativo financeiro. A forma de ocupação alternativa desse espaço é simbolizada por alguns elementos, como o lugar das muIheres na dinâmica confrontacional e o lugar da creche com símbolo central dessa disputa de sentidos, de valores, etc. Esses elementos 
explicitam e reforçam os elementos simbólicos que permitem o reenquadramento da questão da moradia nos moldes do direito à cidade.

\section{O protagonismo das mulheres na dinâmica confrontacional e a creche comunitária como elemento central no repertório}

Não é possível falar da ocupação da primeira Eliana Silva sem escrever sobre duas mulheres: a própria Eliana Silva e a Tia Carminha, representantes e importantes militantes da luta por moradia na Região Metropolitana de Belo Horizonte/MG. Nenhuma delas viu a vila e sua creche, mas os nomes delas estão lá.

Eliana Silva foi uma das fundadoras do MLB em Minas Gerais. Ela foi responsável pela organização das famílias e pelo planejamento das ações que resultaram na ocupação que leva seu nome. Foi presidente da Associação da vila Corumbiara, também situada na Região do Barreiro, uma das primeiras ocupações informais a ser regularizada em Belo Horizonte/ MG. Faleceu em 2009 em decorrência de um câncer, e, depois disso, o movimento acabou se desarticulando.

Tia Carminha era moradora da vila Corumbiara e tornou-se presidente de sua Associação em 2011, assumindo uma posição de liderança dentro do MLB. As reuniões que antecederam à realização da Ocupação Eliana Silva aconteceram em sua casa. Era a organizadora do coral das crianças da vila Corumbiara e, por isso, a creche construída ainda na primeira Ocupação Eliana Silva leva o seu nome. Faleceu pouco depois do Natal de 2011, em decorrência de um ataque cardíaco.
A história da Creche Tia Carminha, para a comunidade, é o relato da resistência e consolidação da ocupação Eliana Silva. A creche representou equipamento fundamental para a reprodução social da comunidade, dado que a sobrevivência de muitas famílias dependia do trabalho e da renda femininos, o que reforça o elemento central do papel feminino na liderança da ocupação. Pouco tempo após a ocupação do terreno, o local recebeu a visita de representantes do Conselho Tutelar de Belo Horizonte, que determinaram um prazo inicial de 24 horas para que fosse providenciado um espaço adequado para abrigar as crianças. Nesse prazo, foi concluída a estrutura provisória em lona e madeira que se destinava à Creche Tia Carminha. Não satisfeitos com a resposta dada pela comunidade, um novo prazo foi estabelecido pelo Conselho Tutelar para a solução do problema. Em apenas uma semana, no ano de 2013, foi erguida uma edificação em alvenaria, e a Creche Tia Carminha começou a funcionar com materiais doados pelos próprios moradores. A creche permaneceu em sua estrutura inicial de alvenaria durante um bom tempo. Ali as crianças faziam suas refeições, e algumas atividades começaram a ser desenvolvidas por moradores e apoiadores voluntários. Superadas as ameaças de despejo, os moradores e apoiadores da vila Eliana Silva iniciaram um projeto de financiamento coletivo através da internet para a arrecadação de recursos que tornariam possível a conclusão da construção da Creche Tia Carminha.

Para os entrevistados, a Creche Tia Carminha representa a união das famílias que integram a vila Eliana Silva, e ela foi, desde o início, um elemento importante na resistência da comunidade contra as tentativas de despejo. 
Figuras 8 e 9 - Creche Tia Carminha um mês após a sua inauguração, em maio de 2015, e após a conclusão das obras de ampliação, em abril de 2017, respectivamente
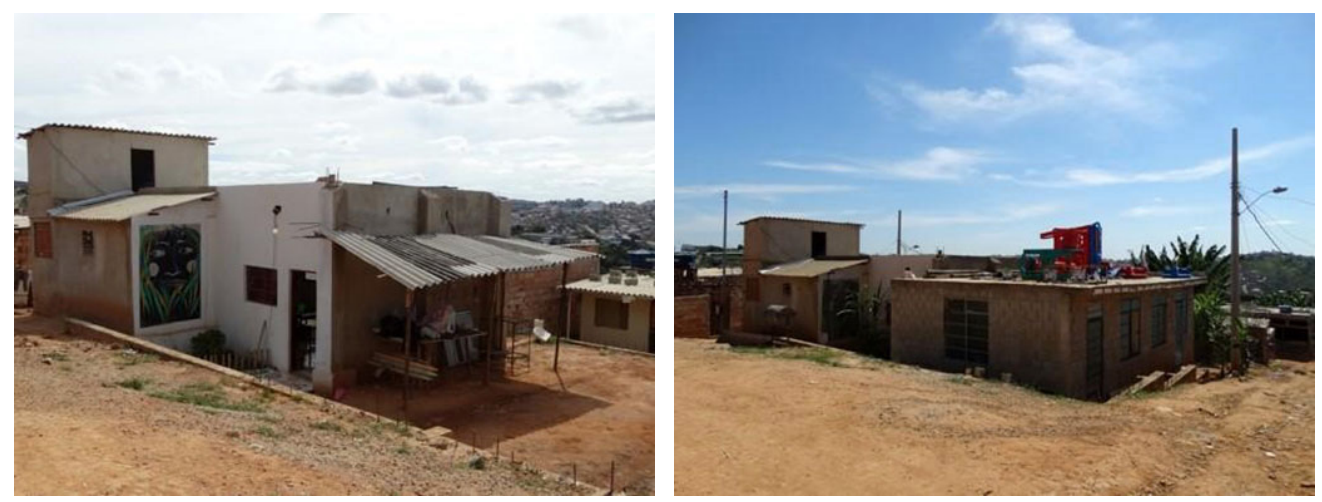

Fonte: arquivo Movimento de Luta nos Bairros, Vilas e Favelas.

Além disso, ressaltam que, na luta pela reforma urbana, moradia e educação desempenham papéis de destaque dentro das ações do MLB. Apontam, ainda, que a creche se configura como o ponto de convergência da rede de apoio às ocupações urbanas de Belo Horizonte, uma vez que seus apoiadores se tornam também apoiadores das lutas pelo direito à moradia e, consequentemente, pela regularização dos assentamentos informais.

A maioria das famílias que integram a vila Eliana Silva é chefiada por mulheres, muitas delas mães. Após a constituição do espaço inicial dedicado à creche, ainda em estrutura de lona, as mulheres começaram a participar mais de diversas atividades, atuando não apenas na cozinha comunitária, mas também nas comissões de segurança, limpeza e estrutura, dentre outras. Atualmente, cerca de 10 moradoras atuam como voluntárias e mantêm a Creche Tia Carminha em funcionamento.
0 ano de 2015 terminou com uma importante conquista para os moradores da vila Eliana Silva. Após diversas tentativas de negociação e manifestações, a Copasa regularizou o sistema de abastecimento de água. Para tanto, todas as edificações - Creche Tia Carminha, casas, biblioteca, etc. - passaram a ter um endereço oficial, e a Ocupação Eliana Silva passou a se chamar vila Eliana Silva. Atualmente, a Creche Tia Carminha atende a mais de 30 crianças da vila Eliana Silva e do seu entorno e se consolidou como espaço de referência para a comunidade. A gestão do local e as atividades pedagógicas são realizadas por mulheres moradoras da própria Vila.

Dentro de uma perspectiva do conflito, o discurso do papel da mulher como mãe e responsável pelo lar é utilizado de uma forma insurgente no momento que a própria luta por moradia é encabeçada por mulheres e que, no caso da comunidade Eliana Silva, quando 
o Conselho Tutelar é acionado para desmobilizar as mulheres envolvidas, a creche surge como elemento fundamental de organização social para permitir a atuação mais estruturada delas. Tanto a cozinha comunitária como a creche se consolidaram como parte do repertório das ocupações numa perspectiva heterotópica na qual se assume a realidade machista dada para que, com isso, possa-se atuar no mundo de uma forma diferente, seguindo a estrutura lógica do pensamento hegemônico para outros fins.

\section{Considerações finais (ou breves considerações para um novo ponto de partida)}

É preciso reconhecer que as disputas partidárias e as descontinuidades de diversos programas e ações desenvolvidos pelo $\mathrm{Mi}$ nistério das Cidades deterioraram a sua capacidade de articulação e efetividade. No entanto, a extinção desse ministério não condiz com a realidade da população brasileira e o necessário enfrentamento das questões urbanas, dentre as quais emerge a pauta do direito à moradia.

Portanto, parece-nos imprescindível para o enfrentamento dessa nova conjuntura a retomada da discussão sobre o importante papel desempenhado historicamente pelos movimentos sociais de luta pela moradia e pela reforma urbana na construção do arcabouço institucional ora mencionado. Além disso, diante da constatação da insuficiência das políticas habitacionais institucionalizadas, especialmente nos últimos 10 anos, e do cenário de retrocessos que se anuncia para os próximos anos, torna-se fundamental o reconhecimento e o fortalecimento destes agentes.

Com isso, a história da vila Eliana Silva e o relato dos seus moradores explicitam a luta pelo efetivo cumprimento da função social da propriedade, estabelecido no texto da Constituição Cidadã de 1988. A consolidação da vila Eliana Silva, bem como das demais ocupações urbanas na $\mathrm{RMBH}$, evidencia o abismo ainda existente entre um arcabouço legal e institucional reconhecido internacionalmente e a urgência da demanda por moradia, além da necessária construção de políticas públicas de habitação que enfrentem, de fato, as questões fundiárias a partir de uma outra lógica de ocupação do espaço urbano.

A história de luta dos moradores da vila Eliana Silva traduz-se na realização do direito à cidade através da luta coletiva. 0 direito à cidade é compreendido aqui para além dos limites do acesso a bens produzidos e localizados na cidade, contemplando o direito de criar e transformar o espaço a partir da luta. A construção dos espaços coletivos da vila Eliana Silva reforça essa compreensão. A Creche Tia Carminha, em especial, tornou-se símbolo de resistência e conquista em face das adversidades e das ameaças impostas.

Essa reflexão também passa pela visão crítica da aposta em estratégias legalistas, sem se aprofundar sobre as reais estruturas de poder. 0 bypass feito pelos interesses econômicos que operam no Congresso Nacional e o executive lobbying feito pelos segmentos do capital interessados no lucro sobre a terra urbana ainda são processos que devem ser mais bem entendidos pela academia. Neste ínterim, o repertório político dos movimentos sociais 
deve se voltar às bases. A perspectiva de criminalização das ocupações remete a um provável adensamento das comunidades existentes e a uma luta mais acirrada em torno das zeis. Passamos por um período de transição em que os prognósticos não são claros. No entanto, argumentamos que é fundamental uma reflexão profunda sobre o seu repertório de ação confrontacional e suas ações estratégicas na atual estrutura de oportunidades políticas. Essa reflexão prática permitirá o fortalecimento dos movimentos com vistas a uma reversão de um quadro político tão adverso às diretrizes da reforma urbana.

\section{[1] https://orcid.org/0000-0002-7691-5894}

Universidade Federal do Rio de Janeiro, Faculdade de Arquitetura e Urbanismo, Instituto de Pesquisa em Planejamento Urbano e Regional. Rio de Janeiro, RJ/Brasil.

themisaragao@gmail.com

\section{[II] https://orcid.org/0000-0002-7432-3545}

Universidade Federal de Minas Gerais, Escola de Arquitetura, Programa de Pós-Graduação em Arquitetura e Urbanismo. Belo Horizonte, MG/Brasil.

anacarolina.soraggi@gmail.com

\section{[III] https://orcid.org/0000-0002-2045-9682}

Universidade Federal do Rio de Janeiro, Faculdade de Arquitetura e Urbanismo, Instituto de Pesquisa e Planejamento Urbano e Regional. Rio de Janeiro, RJ/Brasil.

filipecorrea@ippur.ufrj.br

\section{Notas}

(1) Para um breve relato dos retrocessos na política nacional de habitação de interesse social durante o governo de Michel Temer, conferir Cardoso e Ghilardi (2017).

(2) O Movimento de Luta nos Bairros, Vilas e Favelas (MLB) é filiado à Central dos Movimentos Populares (CMP) e nasceu no final da década de 1990, com atuação nos estados de Minas Gerais e Pernambuco. Em Minas, o movimento surgiu na vila Corumbiara, situada no Barreiro, região limítrofe entre os municípios de Belo Horizonte e Ibirité. Atualmente, atua em todas as regiões do País. De acordo com os entrevistados, militantes do MLB, a pauta do movimento é a luta pela reforma urbana, que tem como carro-chefe as ocupações urbanas. Durante quase duas décadas de existência, o MLB coordenou ações de ocupação de terrenos e edificações ociosos e/ou subutilizados, que não cumprem a sua função social. As áreas ocupadas sob coordenação do MLB caracterizam-se, especialmente, pela organização do espaço através da definição do sistema viário e da subdivisão de lotes, além da definição de áreas de uso coletivo.

(3) Hoje, já são mais de 12 textos diferentes da ONU que reconhecem o direito à moradia. 
(4) Como coroamento desse processo, teve início, em 2007, a elaboração do Plano Nacional de Habitação de Interesse Social - PlanHab, com o objetivo de consolidar os princípios gerais e de estabelecer as metas para a ação governamental em um horizonte temporal de 12 anos, com o objetivo de reduzir o déficit habitacional e de adequar as moradias precárias.

(5) Em sua vertente urbana, o PAC empreendeu as ações de urbanização de assentamentos precários. Contudo, tendo em vista outros aspectos da agenda política que englobam atores com interesses relacionados ao empresariamento urbano e à pauta dos megaeventos, as ações do PAC não foram ao encontro das expectativas criadas em torno dos canais de participação popular preconizados pelo SNHIS. Tendo seus recursos contingenciados, as decisões relacionadas às urbanizações seguiram lógicas variadas, a depender do contexto local e da constelação e engajamento dos atores políticos envolvidos.

(6) Ainda não está claro o real impacto do rearranjo das estruturas ministeriais na condução de programas e políticas a cargo dos ministérios anteriores, contudo, essa questão não será explorada neste artigo, pois fugiria aos seus objetivos, apesar de apresentar extrema pertinência para a compreensão do contexto institucional das políticas urbanas no decorrer do governo Bolsonaro.

(7) As ações do Ministério das Cidades estavam baseadas no diálogo direto com as prefeituras, levando-se em consideração as mais diversas variantes nas condições de gestão e natureza das demandas (do maior ao menor porte, metropolitanos ou não, rurais ou urbanos, etc.) e articulando ações e programas em apoio às prefeituras nas áreas de saneamento, habitação, mobilidade e planejamento urbano. Uma das principais preocupações do ministério era o desenvolvimento de ações para a capacitação do corpo técnico municipal com o objetivo de proporcionar as condições para o cumprimento das diretrizes gerais de desenvolvimento urbano, considerando que boa parte dos municípios brasileiros dispõe de limitadas capacidades estatais para a implementação de políticas públicas nessas áreas.

(8) Para uma visão mais detalhada do histórico dos movimentos de luta por moradia, ver Ferreira (2014, cap. 3).

(9) Para mais detalhes sobre os componentes dessa teoria, conferir Gohn (1997, cap. 3).

(10) Aqui há um claro resgate do interacionismo simbólico de Erving Goffman.

(11) Para uma discussão mais aprofundada sobre participação e o controle social nas políticas urbanas, conferir Castro et al. (2011).

(12) Para uma discussão conceitual mais aprofundada sobre o conceito de enquadramento interpretativo, conferir Mendonça e Simões (2012) e Silva, Cotanda e Pereira (2017).

(13) Dados sobre o número de famílias foram informados pelos coordenadores no Movimento de Luta nos Bairros, Vilas e Favelas (MLB).

(14) De acordo com a notícia veiculada na página do Programa de Aceleração do Crescimento (PAC) do governo federal, publicada no dia 11 de maio de 2012, naquele dia "foram entregues, pela presidenta Dilma Rousseff, 1.160 moradias da primeira fase do Programa Minha Casa Minha Vida, na cidade mineira de Betim (MG). Os conjuntos habitacionais Palmeiras I, Palmeiras II e Baviera, localizados no Sítio Poções, na região norte do município, contaram com investimentos de $\mathrm{R} \$$ 53,3 milhões". Disponível em: <http://www.pac.gov.br/noticia/277cf126>. Acesso em: 16 fev 2016. 
(15) De acordo com a reportagem do jornal O Tempo, publicado no dia 12 de maio de 2012, "nesta sexta-feira, cerca de 400 policiais, incluindo o Grupo de Ações Táticas Especiais (Gate) e o Batalhão de Choque, iniciaram a ação de reintegração de posse de um terreno na vila Santa Rita, na região do Barreiro, ocupado por 350 famílias desde o dia 21 de abril". Disponível em <http:// www.otempo.com.br/cidades/após-ação-de-despejo-famílias-permanecem-na-ocupaçãoeliana-silva-no-barreiro 1.423493>. Acesso em: 16 fev 2016.

(16) Entrevista realizada na vila Eliana Silva, dia 5 fev 2016.

(17) Entrevista realizada na vila Eliana Silva, dia 5 fev. 2016.

(18) Enquanto as ruas da cidade eram tomadas pelas manifestações durante o mês de junho de 2013, surgiu, na divisa de Belo Horizonte com o município de Santa Luzia, na RMBH, a ocupação Rosa Leão e, na sequência, vieram as vizinhas Vitória e Esperança. As três ocupações, situadas na região chamada Izidora, abrigam hoje milhares de pessoas (dados não oficiais). A área ocupada, onde a $\mathrm{PBH}$ pretendia realizar uma operação urbana consorciada, é contestada na justiça e configura um dos maiores conflitos fundiários urbanos do País. Recentemente, em novembro de 2018, a mesa de negociação chegou a um acordo com os detentores do direito de propriedade do terreno ocupado para viabilizar a regularização de parte da área.

(19) A Conferência Municipal de Política Urbana - na qual foi aprovada a delimitação das ocupações urbanas de Belo Horizonte como Áreas Especiais de Interesse Social - Aeis - aconteceu em 2014. No entanto, a proposta de revisão do Plano Diretor que incorporava as deliberações da referida Conferência só foi aprovada em 2019, dando origem à lei municipal n. 11.181 de 8/8/2019. Antes disso, em 2017 - no primeiro ano do mandato do atual prefeito de Belo Horizonte, Alexandre Kalil -, a delimitação das Aeis havia sido regulamentada por meio do decreto municipal $\mathrm{n}$. 16.888/2017, resultado de um processo de negociação entre o poder público municipal e os movimentos sociais articulados às ocupações urbanas.

(20) Divulgação da decisão na mídia local disponível em: <https://www.hojeemdia.com.br/ horizontes/após-cinco-anos-desde-invasão-ocupação-izidora-começa-a-ser-regularizada-peloestado-1.637657>. Acesso em: 20 nov 2018.

(21) Para uma discussão sobre as influências teóricas e o paradigma consolidado nas décadas de 1970 e 1980 para a interpretação dos movimentos sociais urbanos, conferir Silva e Ribeiro (1985). Em um trabalho recente, Gohn (2018) buscou fazer um panorama das principais referências teóricas na análise dos movimentos sociais e ações coletivas desde a década de 1970 até 2018 , apontando como as demandas por institucionalização no pós-1988 e as demandas autonomistas do pós-Junho 2013 ampliaram os referenciais utilizados para a análise dos movimentos sociais a partir da introdução de novas questões de pesquisa no campo mais amplo de estudos. 


\section{Referências}

ABRAMO, P. (2007). A cidade com-fusa: A mão inoxidável do mercado e a produção da estrutura urbana nas grandes metrópoles latino-americanas. Revista Brasileira de Estudos Urbanos e Regionais. Rio de Janeiro, v. 9, n. 2, pp. 25-54.

ALONSO, A. (2012). Repertório, segundo Charles Tilly: história de um conceito. Sociologia e Antropologia. Rio de Janeiro, v. 2, n. 3, pp. 21-41.

BARATTO, R. (2018). O que Bolsonaro e Haddad propõem para as cidades brasileiras? Disponível em: <https://www.archdaily.com.br/br/903503/o-que-bolsonaro-e-haddad-propoem-para-ascidades-brasileiras>. Acesso em: 20 nov 2018

BONDUKI, N. (1998). Origens da habitação social no Brasil: arquitetura moderna, lei do inquilinato e difusão da casa própria. São Paulo, Estação Liberdade/Fapesp.

(2008). Política habitacional e inclusão social no Brasil: revisão histórica e novas perspectivas no governo Lula. Revista eletrônica de Arquitetura e Urbanismo. São Paulo, n. 1, pp. 70-104.

BRASIL (1988). Constituição da República Federativa do Brasil. Brasília, Senado Federal.

(2001). Lei n. 10.257 de 10 de julho de 2001. Estatuto da Cidade. Diário Oficial da União, Brasília, 11 jul. Disponível em: http://www.planalto.gov.br. Acesso em: 20 nov 2018

CARDOSO, A. L.; GHILARD, F. H. (2017). Inflexão ultraliberal e os cortes nas políticas habitacionais no Brasil. Disponível em: http://observatoriodasmetropoles.net.br/wp/inflexao-ultraliberal-e-oscortes-nas-politicas-habitacionais-no-brasil/. Acesso em: 11 mar 2019.

CARDOSO, A. L.; RIBEIRO, L. C. Q. (orgs.). (2000). A municipalização das políticas habitacionais - uma avaliação da experiência recente (1993-1996). Rio de Janeiro, Observatório, Ippur/UFRJ-Fase.

CARVALHO, L. B. de (2020). A democracia frustrada: fake news, política e liberdade de expressão nas redes sociais. Internet \& Sociedade, v. 1, n. 1.

CASTRO, R. M.; SANTOS JÚNIOR, O. A.; CARDOSO, A. L.; FERREIRA, R. F. C. F. (2011). Participação e controle social nas políticas urbanas: avanços e limites do Conselho Nacional das Cidades. In: 35응 ENCONTRO ANUAL DA ANPOCS. Anais... São Paulo, Anpocs.

CRUZ, S. V.; KAYSEL, A.; CODAS, G. (2015). Direita, Volver! O Retorno da Direita e o Ciclo Político Brasileiro. São Paulo, Fundação Perseu Abramo.

DARDOT, P.; LAVAL, C. (2017). Comum: ensaio sobre a revolução no século XXI. São Paulo, Boitempo.

FERREIRA, R. F. C. F. (2014). Autogestão e Habitação: entre a utopia e o mercado. Tese de doutorado. Rio de Janeiro, Universidade Federal do Rio de Janeiro.

FRAZÃO, F. (2018). Jair Bolsonaro é vaiado duas vezes em sabatina de municípios. Disponível em: https://politica.estadao.com.br/noticias/eleicoes,jair-bolsonaro-e-vaiado-duas-vezes-emsabatina-de-municipios,70002321079. Acesso em: 20 nov 2018. 
GOHN, M. DA G. (1997). Teorias dos movimentos sociais: paradigmas clássicos e contemporâneos. São Paulo, Loyola.

(2018). Marcos Referenciais Teóricos que têm dado Suporte às Análises dos Movimentos Sociais e Ações Coletivas no Brasil - 1970-2018. Revista Brasileira de Sociologia - RBS, v. 6, n. 14.

GRAZIA, G. (2003). "Reforma urbana e Estatuto da Cidade”. In: RIBEIRO, L. C. Q; CARDOSO, A. L. (orgs.). Reforma urbana e gestão democrática: promessas e desafios do Estatuto da Cidade. Rio de Janeiro, Revan.

MARICATO, E. (2008). Brasil, cidades. Petrópolis, Vozes.

MARICATO, E. et al. (2013). Cidades rebeldes: passe livre e as manifestações que tomaram as ruas do Brasil. São Paulo, Boitempo/Carta Maior.

MCADAM, D.; TARROW, S.; TILLY, C. (2009). Para mapear o confronto político. Lua Nova: Revista de Cultura e Política, n. 76, pp. 11-48

MENDONÇA, R. F.; SIMÕES, P. G. (2012). Enquadramento: diferentes operacionalizações analíticas de um conceito. Revista Brasileira de Ciências Sociais, v. 27, n. 79, pp. 187-201.

RECUERO, R.; GRUZD, A. (2019). Cascatas de Fake News Políticas: um estudo de caso no Twitter. Galáxia (São Paulo), n. 41, pp. 31-47.

ROLNIK, R. (2015). Guerra dos lugares: a colonização da terra e da moradia na era das finanças. São Paulo, Universidade de São Paulo.

ROYER, L. O. (2009). Financeirização da Política Habitacional: Limites e Perspectivas. Tese de doutorado. São Paulo, Universidade de São Paulo.

SANTOS JÚNIOR, O. A. (2019). Participação e Insurgências: ideias para uma agenda de pesquisa sobre os movimentos sociais no contexto da inflexão ultraliberal no Brasil. E-metropolis, n. 34, pp. 13-25.

SHIMBO, L. Z. (2001). "Empresas construtoras, capital financeiro e a constituição da habitação de mercado”. In: MENDONÇA, J. G.; COSTA, H. S. M. (orgs.). Estado e capital imobiliário: convergências atuais na produção do espaço urbano brasileiro. Belo Horizonte, C/Arte.

SILVA, L. A. M.; RIBEIRO, A. C. T. (1985). Paradigma e Movimento Social: por onde andam nossas ideias? Boletim Paulista de Geografia, n. 62, pp. 67-88.

SILVA, M. K. (2018). A apropriação conservadora do ciclo de protestos de 2013: rumo aos protestos anti-Dilma? Lusotopie, v. 17, n. 1, pp. 88-111.

SILVA, M. K.; COTANDA, F. C.; PEREIRA, M. M. (2017). Interpretação e ação coletiva: o "enquadramento interpretativo" no estudo de movimentos sociais. Revista de Sociologia e Política, v. 25, n. 61, pp. 143-164.

SOLANO, E. (2018). O ódio como política: a reinvenção das direitas no Brasil. São Paulo, Boitempo.

SOUZA, M. L. (2003). Mudar a cidade: uma introdução crítica ao planejamento e a gestão urbanos. Rio de Janeiro, Bertrand Brasil. 
TARROW, S. (2009). O poder em movimento: movimentos sociais e confronto político. Petrópolis, Vozes.

TATAGIBA, L.; PATERNIANI, S. Z.; TRINDADE, T. A. (2012). Ocupar, reivindicar, participar: sobre o repertório de ação do movimento de moradia de São Paulo. Opinião Pública. Campinas, v. 18, n. 2, pp. 399-426.

TATAGIBA, L. (2014). 1984, 1992 e 2013. Sobre ciclos de protestos e democracia no Brasil. Política \& Sociedade, v. 13, n. 28, pp. 35-62.

TILLY, C. (1995). Popular Contention in Great Britain, 1758-1834. Cambridge, Harvard University Press.

Texto recebido em 15/mar/2020

Texto aprovado em 25/out/2020 